\title{
The Influence of Incidental and Intentional Vocabulary Acquisition and Vocabulary Strategy Use on Learning L2 Vocabularies
}

\author{
Minoo Alemi \\ Sharif University of Technology, Iran \\ Email: alemi@sharif.ir \\ Alireza Tayebi \\ Sharif University of Technology, Iran \\ Email: alireza_tayebi2008@yahoo.com
}

\begin{abstract}
This study is an attempt to investigate the role of incidental and intentional vocabulary acquisition in addition to the influence of language learning strategy: namely, the use of vocabulary strategy by Iranian EFL learners in learning new vocabularies. Accordingly, this study is two-faceted. First, Part A examines the difference between different modes of presentation, incidental and intentional learning of new vocabularies (i.e., incidental, etymology-based intentional, and meaning-based intentional), and acquisition of new vocabularies. Part B investigates the impact of the use of language learning strategies-in this case vocabulary and reading strategy use using The Language Strategy Use Inventory-on the learning of new vocabularies. Part A, studying the influence of incidental as opposed to intentional presentation and acquisition of vocabularies, involved 30 students (i.e., 26 males and 4 females). Part B of the study, investigating the role of vocabulary learning strategy use, involved 59 students (i.e., 49 males and 10 females). The results of Part $\mathrm{A}$ shown by t-test indicate that, as far as performance of the students on a test of vocabulary acquisition is concerned, there is no significant difference between the two modes-incidental and intentional learning. However, for the same part, linear regression proved that among the vocabularies presented through different modes of presentation, it is vocabularies learned through meaning-based intentional mode that is the most predictive of the performance of the students on a test of vocabulary acquisition. Moreover, as for part $B$, the study found that there is a positive, but weak, correlation between the students' vocabulary strategy use measured by students filling out a self-report questionnaire entitled The Language Strategy Use Inventory developed by Cohen, A, Oxford, L. R, and Chi. J. - and their learning of new vocabularies. Finally, the findings of part $B$ of the study indicate that, as the degree to which the students' use of vocabulary strategy use increases, so does their use of reading strategy use.
\end{abstract}

Index Terms - incidental and intentional learning, explicit and implicit learning, language learning strategies, vocabulary learning strategy use

\section{INTRODUCTION}

In the old days of language teaching, vocabulary learning and teaching were given little importance. As Jo Moir and Paul Nation (2008) write, at one time it was widely assumed that lexical instruction is not essential as it can happen by itself; therefore, the teaching of vocabulary was not popular (Nation, 1990).

However, nowadays, the significance of vocabulary and its significance in learning a language have become more accepted. Vocabulary is a basic component of language proficiency which provides the basis for learners' performance in other skills, such as speaking, reading, listening and writing. Griffiths $(2003,2006)$ points out, for example, that recently the significance of teaching vocabulary has been acknowledged.

Gass (1999), similarly, states that learning a second language means learning its vocabulary, suggesting that knowing a lexical item means knowing a number of things. She further mentions that Paribakht and Wesche (1999) note that acquisition of vocabulary is an incremental and perhaps recursive process that involves the integration of various kinds of knowledge along with gaining different levels of ability to make use of that knowledge in communication.

It is said that some deliberate learning strategies such as word part analysis, learning using word cards, and dictionary use (Nation, 2001) are also valuable shortcuts as far as learning vocabulary and vocabulary growth are concerned. Nation also notes that learners need to acquire a few important vocabulary learning strategies such as guessing from context, using word cards, using word parts, using mnemonic techniques, expressing the keyword techniques and making use of dictionaries.

Hedge (2000) also mentions that despite the traditional methodology, recent studies have greatly focused on vocabulary learning and teaching containing the following issues:

-What strategies learners use to acquire vocabularies 
-How learners' mental lexicon is organized

-Why some words are easier to learn than others

Hedge (2000) points out that linguistic studies focus on lexical system and acquisition studies focus on how vocabulary is learned. The idea of how vocabulary is learned is principally related to strategies used by learners as well as approaches to teaching vocabulary. One of the principal controversial issues in vocabulary teaching and learning in the field is how to identify significant approaches and strategies to teaching and learning vocabularies, which result in longer and easier retrieval of the vocabularies.

A classification is available that considers three approaches to vocabulary teaching: 1) incidental learning (i.e., learning vocabularies as the by-product of other activities as reading, listening, etc.) 2) Explicit or intentional instruction and 3) Independent strategy development (Hunt and Beglar, 1998; cited in Richards and Renandya, 2002). As proven by many studies, teaching approaches and learning strategies are two main factors affecting learners' performance. Investigating the effects of different modes of teaching vocabularies-incidental and intentional-on learners' acquisition of new vocabulary items might lead to influential and fruitful pedagogical implications on how to teach vocabularies. In terms of Hedge, (2000) such strategies can be either cognitive (i.e., direct mental operations to understand and store new words) or meta-cognitive (i.e., indirect strategies that facilitate the conscious efforts to remember new words).

Moreover, examining the relationship between learners' use of vocabulary strategy use and learning vocabularies may lead us to pay more attention to the role of learning strategies. Therefore, the current study is basically concerned with main approaches to vocabulary learning and teaching. The use of vocabulary learning strategy is one of the factors investigated by the current study.

\section{LITERATURE REVIEW}

\section{A. Incidental and Intentional Learning in L2 Vocabulary Literature}

As Hulstijn (2003) points out, learning a second language can either mean months and years of "intentional" study, by deliberately committing to memory thousands of words along with grammatical words, or it can mean "incidental" learning by "picking up" structures and lexicon of a language, through getting engaged in a variety of communicative activities, namely reading and listening, while the learner's attention is focused not on the form but on the meaning.

Incidental and intentional learning mainly appear in the area of vocabulary. This is because incidental learning can be applied to both abstract and factual declarative knowledge, while intentional is only applicable to factual knowledge (Hulstijn, 2003).

Hunt and Beglar (1998) point out that many vocabularies are learned incidentally through extensive reading and listening. Accordingly, motivating learners to read and listen extensively can provide them with great opportunities to learn new vocabularies. In terms of Huckin and Coady (1999), too, except for the first few thousand most common words, vocabulary learning predominantly occurs through extensive reading with the learner guessing the meaning of unknown words. This process is incidental learning of vocabulary for the acquisition of new words and is the byproduct of the reading (i.e., not the main focus of the cognitive activity, reading). However, this process of incidental learning of vocabularies occurs gradually as Anderson (1985; cited in Richards and Renandya, 2002) claims. The incidental vocabulary learning, as Hunt and Beglar (1998) point out, can be a useful approach for all language learners at all levels.

Shmidth (1990; cited in Nyiazadeh, 2009), also points out that incidental learning is definitely passive in that it can happen when the focus of attention is on some relevant features of input. However, he believes that since incidental learning is useful in task-based language, pedagogy is still a fruitful area of investigation. He further notes that there is an argument that maintains what is learned-whether incidentally or intentionally - is what is noticed (Erricson \& Simon, 1985; cited in Shmidth, 1996).

So far, many studies have been carried out in the field concerning vocabulary learning/teaching approaches. For instance, Huckin and Coady (1999) investigated the role of incidental and intentional vocabulary acquisition. They conclude that incidental vocabulary learning is not entirely incidental in that learners pay at least some attention to individual words. The other studies are reviewed below.

Huckin and Coady (1999) mention the following advantages of incidental vocabulary learning:

a. It is contextualized, giving the learner a rich sense of word use and meaning.

b. It is pedagogically efficient in that it yields two activities at the same time: vocabulary acquisition and reading.

c. It is more learner-based, in that it is the learner who selects the reading materials.

It is worthy of notice that in a review of 114 studies, Krashen (1989) argued that incidental vocabulary acquisition occurs through operation of his input hypothesis: that reading provides comprehensible and necessary input that eventually leads to acquisition. In addition, Krashen (1989, cited in Hulstijn 2003), points out that acquisition of vocabulary and spelling is achieved through exposure to comprehensible input, in this case, reading.

Wode (1999) in a study of incidental vocabulary acquisition in a foreign language classroom, found that it is important to investigate in detail which properties of IM teaching -late partial English immersion (IM) programs- are best suited to trigger the incidental learning with respect to vocabulary (and other linguistic elements). 
Ellis and He (1999) investigated the roles of modified input and output in the incidental acquisition of word meaning. Their study proved that interactional output which provides opportunities for learners to use new vocabularies contributes to better incidental vocabulary acquisition.

Paribakht and Wesche (1999) also conducted research investigating the relationship between reading and incidental L2 vocabulary acquisition. Their study demonstrated incidental acquisition of new lexical knowledge through reading of thematically related texts; hence, vocabulary knowledge may be acquired as a by-product of reading comprehension. In addition, their study showed that among learners' strategies, inferencing, was the main vocabulary strategy use employed.

Among the other factors, frequency of exposure to new vocabularies is another determining factor in learning vocabulary. Rott (1999) studied the effect of frequency with which words occur in a reading text and the role of reading as an input resource in vocabulary acquisition. Her study examined whether intermediate learners incidentally acquire and retain unknown vocabulary by reading a text. The result of the study indicated that, regarding retention measures on productive vocabulary knowledge, only half of the subjects displayed a significant rate of retention, and on receptive knowledge, all but one experimental group retained vocabularies over four weeks.

Hulstijn (2006) makes a distinction between intentional and incidental learning as "Intentional learning refers to the learning mode in which participants are informed, prior to their engagement in a learning task, that they will be tested afterward on their retention of a particular type of information. Incidental learning refers to the mode in which participants are not forewarned of an upcoming retention test for a particular type of information."

Incidental learning has been defined differently by scholars in the field. For instance, Schmidt (1994a; cited in Hulstijn, 2003) three definitions are presented as follows:

“(i) ... learning without the intent to learn. (ii) ... the learning of one stimulus aspect while paying attention to another stimulus aspect ... incidental learning is learning of one thing (...) when the learner's primary objective is to do something else. (iii) the learning of formal features through a focus of attention on semantic features." Moreover, Hulstijn (1996; cited in Gass, 1999) asserts that the definition of incidental learning is: "learning in the absence of an intention to learn."

In spite of the fact that incidental and intentional learning might seem similar to implicit and explicit learning, respectively, these two dichotomies are not identical. As Paradis (1994a; cited in Hulstijn 2003) points out, since implicit competence is incidentally acquired, is stored implicitly and is used automatically, it means more than incidental learning. Therefore, while incidental vocabulary learning of vocabulary may be a useful way of acquiring vocabularies for most advanced learners, intentional/explicit instruction is essential for beginning learners whose reading ability is limited (Hunt and Beglar, 1998).

Ellis (1994b, cited in Gass 1999) also points out that incidental learning differs from implicit learning in that incidential learning is based on a behaviorist notion "with the meaning of a new word being acquired totally unconsciously as a result of abstraction from repeated exposures in a range of activated contexts" (p.219).

Ellis (2008) defines explicit and implicit knowledge in this way:

"Implicit knowledge is intuitive, procedural, systematically variable, automatic, and thus available for use in fluent unplanned language use. It is not verbalizable. ... Explicit knowledge is conscious, declarative, anomalous, and inconsistent (i.e., it takes a form of 'fuzzy' rules inconsistently applied) and generally accessible through control processing in planned language use. It is verbalizable ... like any type of factual knowledge it is potentially learnable at any age."

On the other hand, explicit learning involves awareness at the time of learning, whereas intentional learning occurs by deliberately attempting to commit new information to memory. Accordingly, with the L2 vocabulary learning, incidental and intentional learning are regarded as two distinct categories, because while intentional learning implies the use of deliberate retention techniques, incidental learning does not (Hulstijn, 2003). Therefore, while incidental vocabulary learning of vocabulary may be a useful way of acquiring vocabularies for most advanced learners, intentional/explicit instruction is essential for beginning learners ,since their reading ability is limited (Hunt and Beglar, 1998).

Suchert (2004; cited in Ellis 2008) defined attention as "a process in which biological mechanisms interact when goal-directed behaviors and stimulus-driven responses converge in action (p.144)".

As for experimental operationalization of incidental and intentional learning (i.e., type 1 and type 2 design), as mentioned in Hulstijn's study, two experimental methods are employed usually. The first one is type 1 design, or between group one, which was employed in earlier studies aimed at demonstrating that while incidental learning exists, intentional learning is superior to incidental learning. On the other hand, in within-group type 2 design is within group, which has been used in later studies, is the one employed in the present study. In this design type 2 some additional stimuli in addition to some main stimuli are presented to learners. Retention of these additional stimuli are also tested unexpectedly afterwards, while the students expect to be tested on main materials.

Methodologically, if learners are told in advance of the treatment that they will be tested on the material this is intentional learning, whereas if they are not told, those materials would be considered to be learned incidentally (Hulstijn, 2003). This methodology was followed by the present study, so that the participants were told that they will 
be tested only on their knowledge of bold type -intentional- vocabularies. To their surprise, they were also tested on their knowledge of not bold type-incidental- vocabularies appearing in the reading texts.

\section{B. Language Learning Strategy}

Ever since 1975, when Rubin brought out the concept of language learning strategies for the first time, many, many studies have been carried out to investigate the role of this construct and its influence on learning an L2 in general, and vocabulary acquisition, in particular.

As Wenden (1985; cited in Griffiths, 2006) says, an old proverb states: " 'Give a man a fish and he eats for a day. Teach him how to fish and he eats for a lifetime.' " According to the meaning implied by this proverb, the teachers should provide the students with some fruitful techniques that may help them learn better without the direct help of teachers (hence, making them autonomous).

Tajeddin (2006), in a similar vein, points out that there has been a shift from the methods of teaching to the learner's characteristics, and accordingly, their influence on process and product of language learning. He further notes that a discrepancy exists pertaining to the effect of frequency of strategy use and its effect on the achievement of language proficiency.

Lawson and Hoghen (1996) similarly, note that theorists nowadays put an emphasis on the importance of developing autonomous learning strategies by foreign language learners. Moreover, books demand that teachers provide their students with language learning strategies and encourage them to use them (McCarthy, 1990; Nation; 1990; Oxford; 1990; cited in Lawson and Hoghen, 1996).

The importance of language learning strategies are once more highlighted by Grainger (2005) who mentions that, among many factors, that second language research has been identified to have an impact on proficiency of language learners' language learning strategies. He goes further and defines language learning strategies as techniques that are consciously used by a learner to assist him or her purposely in the language learning process. These techniques in terms of Grainger (2005) can fall into subgroups which are known as "factors or groupings" which indicate special kinds of strategies such as cognitive, metacognitive, social, affective or compensatory. He concludes that language learning strategy use in learning a second language is related to proficiency or achievement (p.2). The current study too, attempts to investigate the link between vocabulary use and vocabulary acquisition.

In addition, Griffiths (2006), points out that the pioneering work in the field of language learning strategies was carried out by Rubin (1975) and Stern (1975) during the mid-'70s. Nevertheless, after a quarter of a century, the language learning strategy field is characterized by "no consensus" (O’Melley et al, 1985a: 22; cited in Griffiths, 2006) and the concept of language learning strategies still remains "fuzzy" (Ellis, 1994: 539; cited in Griffiths, 2006).

However "fuzzy" it might appear, there are some operational definitions of this construct. For instance, Oxford (1990) points out that learning strategies are those steps taken by learners in order to enhance their own learning and that these are especially important for learning a language. This is because they are essential for developing communicative competence. She also notes that by using language learning strategies an improved proficiency and greater self-confidence is achieved. She suggests that the steps taken by students to enhance their own learning are called strategy. Strategies are considered to be tools for gaining autonomous involvement, an essential factor for development of communicative competence.

Many other researchers (Donato and MacCormick, 1994; Ellis, 1994; McDounough, 1999; Wenden, 1998; cited in Gao, 2006) declare that learning strategy research is mostly concerned with listing and classifying language learning strategy use. This can help make association between strategy use and various factors to develop strategy use of language learners. In addition, he points out that other research indicates that the use of strategy is a dynamic phenomenon and varies across contexts, and therefore, is contextual and temporary. In other words, strategy use is dependent on and related to the specific tasks and particular situations, so not all of them can be used in all situations. That is why they are temporary and context-bound.

Most of the studies are mainly concerned with theoretical considerations of language learning strategies (Griffiths, 2008). Rubin (1975; cited in Oxford, 2002) for instance, asserts that good language learners: "a- willingly and accurately guess, b- want to communicate, c- are inhibited about mistakes, $d$ - focus on both structure and meaning, etake advantage of all practice opportunities, and f- monitor their own speech and that of others". In a similar vein, (Naiman, Frohlich, \& Todesco, 1975; cited in Oxford, 2002) add that successful language learners pay attention to effective aspects of language learning and think in language. It should also be noted that no language learner uses just one strategy for vocabulary acquisition (Farhady, 2006).

There are some operational definitions of this construct however "fuzzy" they might appear. For instance, Oxford (1990) points out that learning strategies are those steps taken by learners in order to enhance their own learning and that these are especially important for learning a language. This is because they are essential for developing communicative competence. She also notes that by using language learning strategies an improved proficiency and greater self-confidence is achieved. She suggests that the steps taken by students to enhance their own learning are called strategy. Strategies are considered to be tools for gaining autonomous involvement, an essential factor for development of communicative competence.

According to O'Malley and Chamot (1990, p: 2; cited in Farhady2006), learning strategies are "special ways of processing information that enhance comprehension, learning or retention of information". Oxford (1990) points out 
that learning strategies are those steps taken by learners in order to enhance their own learning. These are especially important for learning a language in that they are essential for developing communicative competence. She also notes that by using language learning strategies, an improved proficiency and greater self-confidence is achieved.

O'Malley et al. (1985a, cited in Griffiths, 2006), use the "operations or steps used by a learner that will facilitate the acquisition, storage, retrieval or use of information" (p. 23) as the definition of the language learning strategies. And, Rubin (1975, p. 43; cited in Griffiths, 2008) declares "strategies are the technique or devices which a learner may use to acquire knowledge".

Oxford (1990; cited in Griffiths, 2003) defines strategies as "learning strategies are specific actions taken by the learner to make learning easier, faster, more enjoyable, more self-directed, more effective, more transferable to new situations" (p. 8). However, Griffiths defines language learning strategies in this way: "specific actions consciously employed by the learner for the purpose of learning language".

Researching language learning strategies in the field, finally, has come to this definition of this construct: that "... strategies that contribute to the development of the language system which the learner constructs and (which) affect learning directly" (Rubin, 1987, p. 23; cited in Leavell and Nam, 2006).

However, there are some conditions under which the use of language learning strategies are useful: "a- the strategy relates well to the L2 task at hand, b- the strategy fixes the particular students' learning style preferences to one degree or another, and c- the student employs strategy effectively and links it with other relevant strategies" (Ehrman, \& Leaver, and Oxford, 2003).

Recent research, as Leavell and Nam point out, has aimed at determining a connection between strategy use and language proficiency (Green and Oxford, 1995; Oxford and Ehrman, 1995). The result of such research indicates that more proficient language learners employ more strategies compared with less proficient learners (p.2). He further notes that research has shown that there exists a difference between male and females regarding their use of strategies, so that females use more strategies than males (Ehrman and Oxford, 1989; Green and Oxford, 1995; Oxford, 1993; cited in Leavell and Nam, 2006). The relationship between the language learning strategy use, namely, vocabulary learning strategy use, and vocabulary acquisition is one of the main concerns of the present study, as aforementioned.

\section{Vocabulary Learning Strategy}

In recent years, the importance of vocabulary acquisition has been emphasized by researchers and commentators, in that vocabulary acquisition plays a crucial role in learning a second language (Allen, 1983; Laufer, 1986; Nation, 1990; Richards, 1980; cited in Lawson and Hoghen, 1996). However, there is a lack of consensus regarding the conceptualization of the process concerning what contributes to vocabulary acquisition. For example, "the importance of the context use for acquiring vocabulary, and the extent to which students do develop specific strategies for vocabulary learning during their language studies" (Lawson and Hoghen, 1996). They point out that another determining factor concerning vocabulary acquisition is the importance of context and the value of reading (Moulton, 1966, Twaddle, 1980, Parreren; cited in Mondria \& Wit-De-Doer, 1991).

Different scholars identify vocabulary learning strategies differently, some of which are: 1). memorization strategies, 2) repetition strategies, 3) association strategies, 4) key word method, 5) inferencing strategy, 6) dictionary use (Cohen and Macaro, 2007), 7) sematic grid strategies, 8) word lists (Farhady, 2006). According to Farhady (2006), applying certain types of strategies forms an approach to vocabulary learning that influences the level of foreign language proficiency. In other words, appropriate strategy use results in improved achievement in specific skills or sub-skills. Moreover, language proficiency also affects the use of particular vocabulary strategy use.

\section{Purpose of the Study}

The current study is an attempt to broaden our knowledge of vocabulary acquisition by investigating the effect of different modes of teaching vocabularies in terms of incidental and intentional, along with the effect of vocabulary and reading strategy use, and its effect on or relationship to vocabulary acquisition. Accordingly, the current study has focused on teaching vocabulary and the effect of learning strategy use by learners and their success in learning vocabulary and the relationship between the two.

\section{E. Research Questions}

With regard to the nature and purpose of this study, the following questions are posed:

1-Is there any difference between different modes of teaching vocabularies in terms of incidental and intentional teaching and learning, and the acquisition of vocabularies by Iranian EFL learners?

2-Is there a relationship between Iranian EFL learners' use of Vocabulary Strategy and their ability to acquire new vocabularies?

3-Is there a relationship between Iranian EFL learners' Vocabulary Strategy use and Reading Strategy use?

4-From among the three modes of presentation and acquisition of new vocabulary items (i.e., incidental, etymologybased intentional, meaning-based intentional), which one has the most impact on Iranian EFL learners' performance on a test of vocabulary acquisition including all the target words presented through these three modes of presentation?

As for the distinction between the meaning-based and etymology-based intentional learning it should be explained that, those vocabularies whose meanings are presented via marginal glossary fall in the meaning-based intentional type, 
and those vocabularies whose meanings are presented by analyzing their roots, prefixes and suffixes are in the category of etymology-based intentional.

\section{F. Hypothesis}

$\mathrm{H}_{0}$ 1: There is no difference between different modes of teaching vocabularies in terms of incidental and intentional teaching and learning, and the acquisition of vocabularies by Iranian EFL learners.

$\mathrm{H}_{0}$ 2: There is a relationship between Iranian EFL learners' use of vocabulary strategy and their ability to acquire new vocabularies

$\mathrm{H}_{0}$ 3: There is a relationship between Iranian EFL learners' vocabulary strategy use and reading strategy use.

$\mathrm{H}_{0}$ 4: There is no difference between Iranian EFL learners' acquisition of new vocabularies taught incidentally or intentionally (i.e., meaning-based and etymology based).

\section{Methodology}

\section{A. Participants}

Part A of the study (i.e., studying the difference between incidental and intentional vocabulary learning) involved 30 students from different majors passing the General English Course at Sharif University of Technology. They were Persian native speakers who have studied English at least four years at high school. The age of the subjects ranged from 18 to 20 . The majority of students were male $(\mathrm{N}=26)$ and the rest were female $(\mathrm{N}=4)$.

Part B of the study (i.e., investigating the relationship between vocabulary and reading strategy use and the achievement on post-test as the index of vocabulary knowledge) involved 59 students with characteristics similar to the students of part A of the study as aforementioned. The number of participants in terms of gender is: males: $(\mathrm{N}=49)$ and females $(\mathrm{N}=10)$.

\section{B. Materials and Procedure}

The Language Strategy Use Inventory (developed by Cohen, A, Oxford, L. R, and Chi, J.), a self-report questionnaire, was used to measure the students' vocabulary and reading strategy use. In this questionnaire, a trusted measure, language learning strategies are grouped into six categories for assessment: listening, speaking, vocabulary, reading, writing, translation strategy use.

The language strategy use inventory makes use of four Likert-type responses for each strategy item ranging from 1 to 4 (i.e., from "this strategy doesn't fit for me" to "I use this strategy and like it"). In the current study, participants were asked to respond to each item based on their use of the strategies mentioned.

All of the participants $(\mathrm{N}=59)$ also were asked to take the pretest, which was administered one week prior to the study. The pre-test consisted of 32 items from which 12 were selected as the Target Words (TWs). These 12 items were the ones which 30 students (26 males and 4 females) didn't know (i.e., answered these 12 items incorrectly). Therefore, these 12 target words and the 30 students formed the part A of the study and were the main subjects of the post-test, which was administered three days after the introduction of the treatment.

The post-test consisted of the 12 target words (TWs) in addition to six more items (two incidentals, two intentional meaning-based and two intentional etymology-based). The 12 TWs consisted of four incidental vocabularies, four meaning-based intentional vocabularies, and four etymology-based intentional vocabularies. These 12 words were the ones presented in pretest as well-TWs.

Two chapters of the book English for Science \& Engineering Students — written by Alemi et al (2009) — were taught by the teacher/researcher of the study. These two chapters consist of several parts: namely, reading text, vocabulary study, idioms and collocation, grammar, writing section. The reading text and vocabulary sections of chapters 9 and 10 of the book were concerns of the current study in which TWs, both incidental and intentional ones, were included. The meaning of the incidental words was not taught directly, so that by explaining and focusing on the content of the tests these vocabularies were taught. Intentional words were those words which were typed bold in the texts of reading sections. These words were focused on so that the meanings of meaning-based intentional words were taught by proving their meaning in marginal-glossary appearance in footnotes. Etymology-based intentional words were taught by analyzing the words into their prefixes and roots and suffixes which appeared at the end of the texts along with their meanings.

To follow the methodology of incidental and intentional research, the students were told in advance of doing the research that they would be tested on these bold-typed vocabularies. However they weren't told that they would also be tested on the incidental words-not bold-typed. But, unexpectedly they were tested on these words as well.

Therefore, the students consciously and by paying attention to the intentional words learned them, whereas their focus was on the content of the reading texts while learning incidental words.

\section{Data Analysis}

The performance of the students on posttest was analyzed by paired t-test so that the scores achieved on different subsections of the posttest were compared with each other separately. That is to say, the scores of incidentally acquired 
vocabularies as well as those of etymology-based intentionally and meaning-based intentionally learned vocabularies were compared.

In addition, Spearman correlation was run in order to show how much students' gender correlate with their use of vocabulary learning strategy and reading strategy use, separately. Also, Spearman correlation was measured to know how much the participants' vocabulary strategy use correlated with their reading strategy use.

Moreover, in order to find out that from these three modes of presentation and acquisition of vocabularies (i.e., incidental, etymology-based intentional and meaning-based intentional) which one has the most impact on the ultimate performance on the test of vocabulary acquisition, linear regression was calculated. (All of the statistical procedures are available in Appendices).

\section{RESULTS AND DISCUSSION}

To answer the first research question, the result of the t-test indicates that the participants mean score of incidentally acquired vocabularies was $2.90(\mathrm{M}=2.90, \mathrm{SD}=0.95)$, the mean score of etymology-based intentionally learned vocabularies was $2.63(\mathrm{M}=2.63, \mathrm{SD}=0.88)$, and the mean score of meaning-based intentionally learned vocabularies was $3.03(\mathrm{M}=3.03, \mathrm{SD}=0.80)$. Therefore, the subjects performed best on the items testing their knowledge of meaningbased intentionally learned vocabularies, as the mean shows.

Regarding the difference among incidentally acquired vocabularies, and etymology-based intentionally, and meaning-based intentionally learned vocabularies, the results of three paired t-tests indicate that there is not any significant difference between the participants' performance on each subgroup of the test. That is to say, the difference between meaning-based and etymology-based intentionally learned vocabulary items is $1.88(\mathrm{t}=1.88, \mathrm{df}=29, \mathrm{sig}=0.07)$. As for the difference between meaning-based intentionally and incidentally learned vocabularies, paired t-tests again show that there is not a significant variation between the participants' mean score on the posttest $(\mathrm{t}=0.66, \mathrm{df}=29$, sig=0.51). Concerning the last comparison, the comparison between incidentally and etymology-based intentionally learned vocabularies, again, no significant difference was observed $(\mathrm{t}=-1.39, \mathrm{df}=29$, sig=0.17).

Gass (1999) argues being able to prove that a word is learned incidentally, in that there is no direct way to know what a learner is doing, is one of the main difficulties in the concept of incidental learning. She mentions that the American Heritage Dictionary of English Language defines incidental as follows: "occurring as a fortuitous or minor concomitant." So incidental learning is a by-product of doing something else.

As for the second question, the Spearman correlation indicates that vocabulary strategy use and acquisition of new vocabularies are weakly correlated $(\mathrm{r}=0.006)$. However, concerning the third question, the results indicate that there is a significant relationship between students' use of vocabulary strategy use and reading strategy use $(\mathrm{r}=0.398, \mathrm{sig}=0.002)$, which, according to table 1 , is significant at .01 level of significance.

Correlations

TABLE 1

SPEARMAN CORRELATION BETWEEN VOCABULARY AND READING STRATEGY USE

\begin{tabular}{|lll|l|l|}
\hline & & $\begin{array}{l}\text { Vocabulary Strategy } \\
\text { Use }\end{array}$ & $\begin{array}{l}\text { Reading Strategy } \\
\text { Use }\end{array}$ \\
\hline $\begin{array}{l}\text { Spearman's } \\
\text { rho }\end{array}$ & Vocabulary strategy use & $\begin{array}{l}\text { Correlation } \\
\text { Coefficient }\end{array}$ & 1.000 & $.398(* *)$ \\
& & Sig. (2-tailed) &. & .002 \\
& $\mathrm{~N}$ & 59 & 59 \\
& \multirow{3}{*}{ Reading strategy use } & Correlation & $.398(* *)$ & 1.000 \\
& & Coefficient \\
& Sig. (2-tailed) & .002 &. \\
& $\mathrm{~N}$ & 59 & 59 \\
\hline
\end{tabular}

** Correlation is significant at the 0.01 level (2-tailed).

As for the last question, through the statistical procedure of linear regression, it was found that in a test of vocabulary including incidentally and meaning-based intentionally and etymology-based intentionally learned vocabulary items, it is the participants' knowledge of meaning-based intentionally learned vocabularies that determines how well they will perform on the vocabulary test.

\section{CONCLUSION}

Concerning the findings of the current study, a couple of suggestions are made to follow in further research. As mentioned above, the mean score of meaning-based intentionally learned vocabularies is 3.03 , which is the highest mean compared with the mean scores of etymology-based intentionally and incidentally acquired vocabularies. However, as the results of the statistical procedure of t-test indicate, there is not any significant difference among acquisition of these three kinds of words through three modes of presentation. This might be explained using the words of Huckin and Coady (1999), who posit that, incidental vocabulary learning is not entirely incidental in that learners pay 
at least some attention to individual words. Accordingly, the to-be-incidentally-acquired vocabularies have not been acquired purely incidentally. In addition, that the nature of some of the vocabularies which were going to be acquired incidentally, was such that could yield itself to the same analytical procedures that have been used to convey and teach the meaning of etymology-based intentionally learned vocabularies, supports the claim made by Huckin and Coady.

As Griffiths (2006) points out, language learning strategies, irrespective of the type, are employed more frequently by higher-level learners as indicated by a large-scale study of university students in Puerto Rico, by Green and Oxford (1995). Too, Oliver and Magogwe (2007) point out that there is a link between language proficiency and the use of language learning proficiency (e.g., Green and Oxford 1995; Khaldieh, 2000; Wharton, 2000) the overall pattern being that as the use of strategies increases so does language proficiency. The present study, on the contrary, found that vocabulary strategy use and acquisition of new vocabularies are weakly correlated ( $\mathrm{r}=0.006)$.

There are two important factors concerning the role of language learning strategy use and its applications in teaching and learning an L2, in light of which the result pertaining to the relationship between the use of learning strategy and proficiency may be discussed. One of these factors, as Griffiths (2006) points out, is that language learning strategies cannot be observed directly, which is one of the difficulties with researching this construct, in that they can only be inferred from language learner behavior. Griffiths (2003) also points out that only a few language learning strategies such as dictionary use are observable and can be directly measured, and that the rest must be inferred from the behavior of language learner is one of the difficulties in researching this construct. The use of vocabulary learning strategy was more like the kinds of strategies that are not directly observable. Perhaps the students' reports on their use of vocabulary learning strategy were not truly representative of how they learn vocabularies. Therefore, it is suggested that instead of just measuring the participant's use of vocabulary leaning strategy (and/or any other type of learning strategy) by asking them to fill out the self-report questionnaire, one or more ways of measuring the use of this construct be used, such as observations, interviews, and the like.

Secondly, as asserted by Griffiths (2008), in addition to strategies, many other learner variables can potentially affect the outcome of language learning efforts, such as aptitude, learning style, motivation, age, belief, culture, gender, personality, metacognition or autonomy. She also states that learning variables, too, can affect the final efforts of language learning, namely vocabularies, grammar, pronunciation, function, skill, teaching/learning methods, strategy instruction, error correction, or task. Taking all of the factors affecting the outcome of language learning mentioned by Griffiths into account, it might be concluded that the learners might have used those strategies as they reported on the questionnaire, but these underlying factors have been influential and have rendered the results unpredictable.

The other finding of the study is that there is a significant relationship between students' use of vocabulary strategy use and reading strategy use. This is a logical finding due to the fact that many students prefer to use learning strategies in every aspect of the task of learning a language, perhaps because they are "good language learners" who have found it a fruitful and constructive activity.

It has been also found that it is the participants' knowledge of meaning-based intentionally learned vocabularies that mostly influences how well they will perform on the vocabulary test. It might be due to the fact that the number of TWs falling in each category (i.e., incidental, etymology-based intentional and meaning-based intentional) was only four. To confirm this finding it is suggested that more research be done involving many more TWs.

Regarding the nature of the vocabularies which are supposed to be acquired incidentally, in further research, it is suggested that vocabularies which cannot be divided into prefix and root and suffix be selected; otherwise, the students will get used to analyzing them as they do so when it comes to learning etymology-based intentional vocabularies.

It is one of the influential limitations of the study that no control group was involved. Further research is needed including a control group studying the impact of incidental and intentional learning on acquisition of vocabulary items.

Last, but not least, as Griffiths (2003) points out, studies exploring language learning strategies with regard to sex are not common. The current study also, due to the fact that the proportions of males and females were not the same, has not investigated the role of gender. It is suggested that further research be done taking into account the effect of sex on the use of language learning strategy use.

\section{APPENDIX A. COMPARISONS OF DIFFERENT PARTS OF POST-TEST (T-TESTS)}

\begin{tabular}{|ll|c|c|c|c|}
\hline \multicolumn{1}{|c}{ PAIRED SAMPLES STATISTICS } \\
\cline { 3 - 6 } & & Mean & $\mathrm{N}$ & Std. Deviation & Std. Error Mean \\
\hline Pair 1 & posmean & 3.0333 & 30 & .80872 & .14765 \\
& posetym & 2.6333 & 30 & .88992 & .16248 \\
\hline
\end{tabular}

PAIRED SAMPLES CORRELATIONS

\begin{tabular}{|lc|c|c|c|}
\hline & $\mathrm{N}$ & Correlation & Sig. \\
\hline Pair 1 & posmean \& posetym & 30 & .065 & .731 \\
\hline
\end{tabular}


PAIRED SAMPLES TEST

\begin{tabular}{|c|c|c|c|c|c|c|c|c|}
\hline & $\begin{array}{l}\text { Paired I } \\
\text { Mean }\end{array}$ & $\begin{array}{l}\text { ifferences } \\
\text { Std. } \\
\text { Deviation } \\
\end{array}$ & $\begin{array}{l}\text { Std. } \\
\text { Error } \\
\text { Mean } \\
\end{array}$ & $\begin{array}{l}95 \% \text { Cor } \\
\text { Interval } \\
\text { Differen }\end{array}$ & $\begin{array}{l}\text { dence } \\
\text { the }\end{array}$ & Mean & $\begin{array}{l}\text { Df } \\
\text { Std. } \\
\text { Deviation }\end{array}$ & $\begin{array}{l}\text { Sig. (2-tailed) } \\
\text { Std. Error Mean }\end{array}$ \\
\hline & Lower & Upper & Lower & Upper & Lower & Upper & Lower & Upper \\
\hline $\begin{array}{l}\text { Pair posmean - posetym } \\
1\end{array}$ & .40000 & 1.16264 & .21227 & -.03414 & .83414 & 1.884 & 29 & .070 \\
\hline
\end{tabular}

\begin{tabular}{|ll|l|l|l|l|}
\hline \multicolumn{6}{|c|}{ PAIRED SAMPLES STATISTICS } \\
\hline & & & & \\
& & Mean & $\mathrm{N}$ & Std. Deviation & Std. Error Mean \\
\hline Pair 1 & posmean & 3.0333 & 30 & .80872 & .14765 \\
& posincid & 2.9000 & 30 & .95953 & .17518 \\
\hline
\end{tabular}

PAIRED SAMPLES CORRELATIONS

\begin{tabular}{|ll|l|l|c|}
\hline & $\mathrm{N}$ & Correlation & Sig. \\
\hline Pair 1 & posmean \& posincid & 30 & .227 & .228 \\
\hline
\end{tabular}

PAIRED SAMPLES TEST

\begin{tabular}{|r|l|l|l|l|l|l|l|l|}
\hline \multirow{2}{*}{} & \multicolumn{9}{|c|}{ Paired Differences } & t & Df & Sig. (2-tailed) \\
\cline { 2 - 9 } & Mean & $\begin{array}{l}\text { Std. } \\
\text { Deviation }\end{array}$ & $\begin{array}{l}\text { Std. Error } \\
\text { Mean }\end{array}$ & $\begin{array}{l}\text { 95\% Confidence Interval of } \\
\text { the Difference }\end{array}$ & Mean & $\begin{array}{l}\text { Std. } \\
\text { Deviation }\end{array}$ & \\
\cline { 2 - 9 } & Lower & Upper & Lower & Upper & Lower & Upper & Lower & Upper \\
\hline $\begin{array}{r}\text { Pair 1 posmean } \\
\text { - posincid }\end{array}$ & .13333 & 1.10589 & .20191 & -.27961 & .54628 & .660 & 29 & .514 \\
\hline
\end{tabular}

PAIRED SAMPLES STATISTICS

\begin{tabular}{|ll|l|l|l|l|}
\hline & & Mean & $\mathrm{N}$ & Std. Deviation & Std. Error Mean \\
\hline Pair 1 & Posetym & 2.6333 & 30 & .88992 & .16248 \\
& Posincid & 2.9000 & 30 & .95953 & .17518 \\
\hline
\end{tabular}

\begin{tabular}{|c|c|c|c|}
\hline & $\mathrm{N}$ & Correlation & Sig. \\
\hline Pair 1 posetym \& posincid & 30 & .359 & .051 \\
\hline
\end{tabular}

\begin{tabular}{|c|l|l|l|l|l|l|l|l|}
\hline \multicolumn{1}{|c|}{} & \multicolumn{9}{c|}{ PaIRED SAMPLES TEST } & Differences & Df & Sig. (2-tailed) \\
\cline { 2 - 9 } & & $\begin{array}{l}\text { Std. } \\
\text { Deviation }\end{array}$ & $\begin{array}{l}\text { Error } \\
\text { Mean }\end{array}$ & $\begin{array}{l}\text { 95\% Confidence } \\
\text { Interval of the } \\
\text { Difference }\end{array}$ & Mean & $\begin{array}{l}\text { Std. } \\
\text { Deviation }\end{array}$ & Std. Error Mean \\
\cline { 2 - 10 } & Lower & Upper & Lower & Upper & Lower & Upper & Lower & Upper \\
\hline $\begin{array}{c}\text { Pair 1 posetym }- \\
\text { posincid }\end{array}$ & -26667 & 1.04826 & .19139 & -.65809 & .12476 & - & 29 & .174 \\
\hline
\end{tabular}

\section{APPENDIX B. CORRELATIONS}

\begin{tabular}{|lll|l|l|}
\hline \multicolumn{3}{|c|}{ CORRELATIONS } \\
\hline Spearman's rho & vocabstrat & Correlation Coefficient & vocabstrat & posttotal \\
& & Sig. (2-tailed) & .000 & .006 \\
& & $\mathrm{~N}$ & .964 \\
& \multirow{2}{*}{ posttotal } & Correlation Coefficient & .006 & 59 \\
& & Sig. (2-tailed) & .964 &. \\
& $\mathrm{~N}$ & 59 & 59 \\
\hline
\end{tabular}




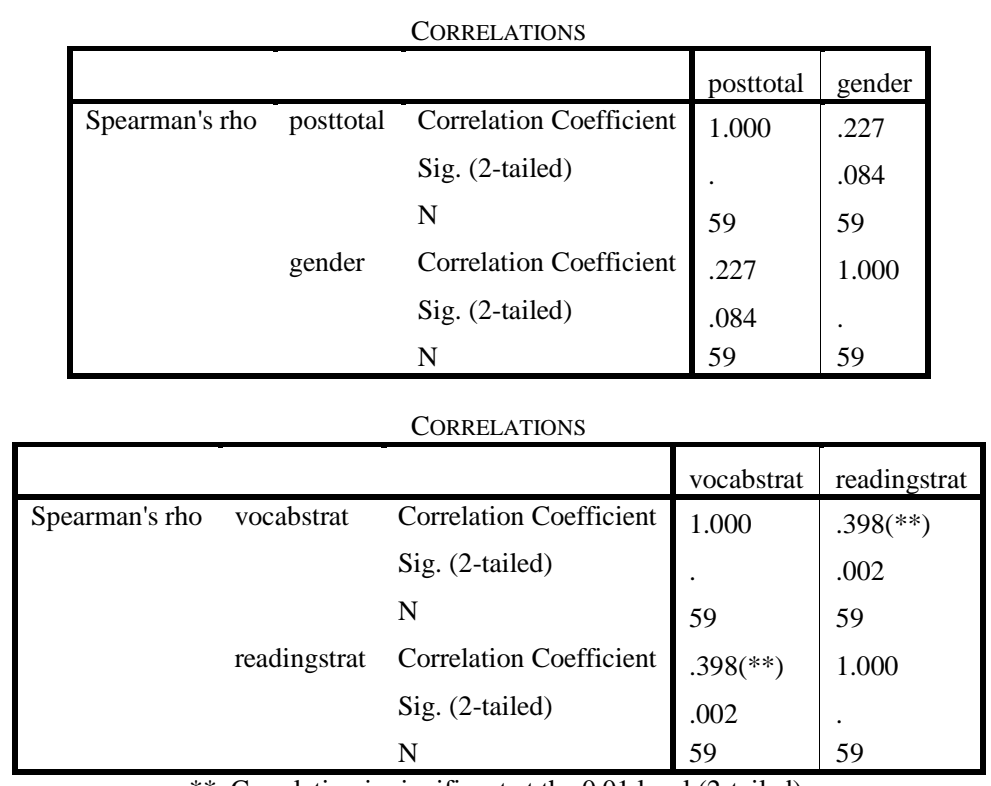

** Correlation is significant at the 0.01 level (2-tailed).

\begin{tabular}{|c|c|c|c|c|}
\hline \multicolumn{5}{|c|}{ CORRELATIONS } \\
\hline & & & vocabstrat & gender \\
\hline \multirow[t]{6}{*}{ Spearman's rho } & vocabstrat & Correlation Coefficient & 1.000 & -.049 \\
\hline & & Sig. (2-tailed) & & .711 \\
\hline & & $\mathrm{N}$ & & 59 \\
\hline & gender & Correlation Coefficient & -.049 & 1.000 \\
\hline & & Sig. (2-tailed) & .711 & \\
\hline & & $\mathrm{N}$ & 59 & 59 \\
\hline
\end{tabular}

\begin{tabular}{|c|c|c|c|c|}
\hline \multicolumn{5}{|c|}{ CORRELATIONS } \\
\hline & & & gender & readingstrat \\
\hline \multirow[t]{6}{*}{ Spearman's rho } & gender & Correlation Coefficient & 1.000 & .004 \\
\hline & & Sig. (2-tailed) & . & .976 \\
\hline & & $\mathrm{N}$ & 59 & 59 \\
\hline & readingstrat & Correlation Coefficient & .004 & 1.000 \\
\hline & & Sig. (2-tailed) & .976 & 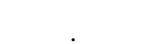 \\
\hline & & $\mathrm{N}$ & 59 & 59 \\
\hline
\end{tabular}

APPENDIX C. DESCRIPTIVE STATISTICS

Statistics

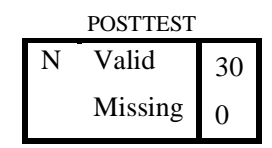

\begin{tabular}{|ll|l|l|l|l|}
\hline \multicolumn{1}{|c|}{ POSTTEST } \\
\hline Valid & 5.00 & 1 & Valid & $\begin{array}{l}\text { Cumulative } \\
\text { Percent }\end{array}$ \\
& 8.00 & 2 & 3.3 & 3.3 & 3.3 \\
& 10.00 & 1 & 6.7 & 6.7 & 10.0 \\
11.00 & 2 & 3.3 & 3.3 & 13.3 \\
12.00 & 6 & 6.7 & 6.7 & 20.0 \\
13.00 & 5 & 20.0 & 20.0 & 40.0 \\
14.00 & 4 & 16.7 & 16.7 & 56.7 \\
15.00 & 6 & 13.3 & 13.3 & 70.0 \\
17.00 & 3 & 20.0 & 20.0 & 90.0 \\
Total & 30 & 10.0 & 10.0 & 100.0 \\
\hline
\end{tabular}


DESCRIPTIVE STATISTICS

\begin{tabular}{|l|l|l|l|l|l|}
\hline & $\mathrm{N}$ & Minimum & Maximum & Mean & Std. Deviation \\
\hline posttest & 30 & 5.00 & 17.00 & 12.9000 & 2.70823 \\
Valid N (listwise) & 30 & & & & \\
\hline
\end{tabular}

\begin{tabular}{|c|c|c|c|c|c|c|}
\hline \multirow{3}{*}{} & \multicolumn{2}{|l|}{ Cases } & \multicolumn{2}{l|}{} \\
\cline { 2 - 8 } & \multicolumn{2}{|l|}{ Valid } & \multicolumn{2}{l|}{ Missing } & \multicolumn{2}{l|}{ Total } \\
\cline { 2 - 8 } & $\mathrm{N}$ & Percent & $\mathrm{N}$ & Percent & $\mathrm{N}$ & Percent \\
\hline posttest & 30 & $100.0 \%$ & 0 & $.0 \%$ & 30 & $100.0 \%$ \\
\hline
\end{tabular}

\begin{tabular}{|lll|l|l|}
\hline \multicolumn{3}{|c|}{ DESCRIPTIVES } \\
\hline \multicolumn{3}{|c|}{} & Statistic & $\begin{array}{l}\text { Std. } \\
\text { Error }\end{array}$ \\
\hline posttest & Mean & 12.9000 & .49445 \\
& 95\% Confidence & Lower & 11.8887 & \\
& Interval for Mean & Bound & & \\
& Upper & 13.9113 & \\
& Bound & & \\
5\% Trimmed Mean & 13.0556 & \\
Median & 13.0000 & \\
Variance & 7.334 & \\
Std. Deviation & 2.70823 & \\
Minimum & 5.00 & \\
Maximum & 17.00 & \\
Range & 12.00 & \\
Interquartile Range & 3.00 & \\
Skewness & -.936 & .427 \\
Kurtosis & 1.488 & .833 \\
\hline
\end{tabular}

posttest Stem-and-Leaf Plot

Frequency Stem \& Leaf

1.00 Extremes $\quad(=<5.0)$

$2.00 \quad 8.00$

.009 .

$1.00 \quad 10.0$

$2.00 \quad 11.00$

6.0012 .000000

$5.00 \quad 13.00000$

$4.00 \quad 14.0000$

$6.00 \quad 15.000000$

.0016 .

$3.00 \quad 17.000$

Stem width: 1.00

Each leaf: 1 case(s)

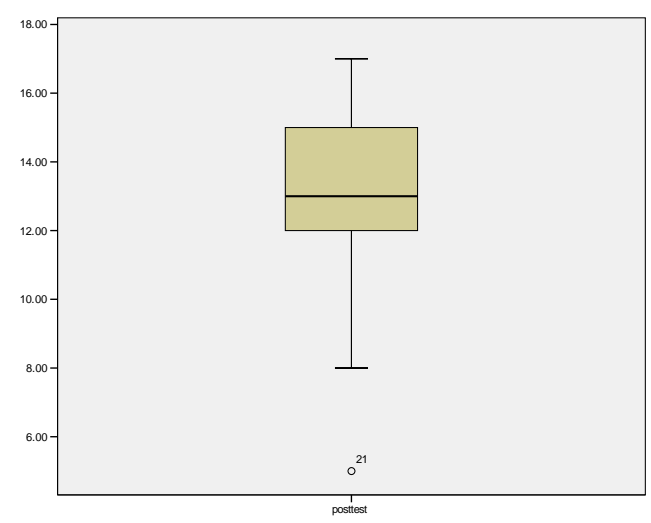


Statistics

\begin{tabular}{|ll|l|}
\hline \multicolumn{2}{|c|}{ POSMEAN } \\
\hline & Valid & 30 \\
& Missing & 0 \\
\hline
\end{tabular}

\begin{tabular}{|c|c|c|c|c|c|}
\hline \multicolumn{6}{|c|}{ POSMEAN } \\
\hline & & Frequency & Percent & Valid Percent & Cumulative Percent \\
\hline \multirow[t]{5}{*}{ Valid } & 1.00 & 1 & 3.3 & 3.3 & 3.3 \\
\hline & 2.00 & 6 & 20.0 & 20.0 & 23.3 \\
\hline & 3.00 & 14 & 46.7 & 46.7 & 70.0 \\
\hline & 4.00 & 9 & 30.0 & 30.0 & 100.0 \\
\hline & Total & 30 & 100.0 & 100.0 & \\
\hline
\end{tabular}

DESCRIPTIVE STATISTICS

\begin{tabular}{|l|l|l|l|l|l|}
\hline & $\mathrm{N}$ & Minimum & Maximum & Mean & Std. Deviation \\
\hline posmean & 30 & 1.00 & 4.00 & 3.0333 & .80872 \\
Valid N (listwise) & 30 & & & & \\
\hline
\end{tabular}

CASE PROCESSING SUMmary

\begin{tabular}{|c|c|c|c|c|c|c|}
\hline & \multicolumn{6}{|c|}{ Cases } \\
\hline & \multicolumn{2}{|c|}{ Valid } & \multicolumn{2}{|c|}{ Missing } & \multicolumn{2}{|c|}{ Total } \\
\hline & $\mathrm{N}$ & Percent & $\mathrm{N}$ & Percent & $\mathrm{N}$ & Percent \\
\hline posmean & 30 & $100.0 \%$ & 0 & $.0 \%$ & 30 & $100.0 \%$ \\
\hline
\end{tabular}

\begin{tabular}{|lll|l|l|}
\hline \multicolumn{3}{|c|}{ DESCRIPTIVES } \\
\hline posmean & Mean & Statistic & $\begin{array}{l}\text { Std. } \\
\text { Error }\end{array}$ \\
& 95\% Confidence & Lower & 3.0333 & .14765 \\
& Interval for Mean & Bound & 2.7314 & \\
& & & \\
& Upper & 3.3353 & \\
5\% Trimmed Mean & Bound & & \\
Median & & 3.0741 & \\
Variance & & 3.0000 & \\
Std. Deviation & & .654 & \\
Minimum & & .80872 & \\
Maximum & & 1.00 & \\
Range & 4.00 & \\
Interquartile Range & & 3.00 & \\
Skewness & 1.25 & \\
Kurtosis & & -.482 & .427 \\
\end{tabular}

posmean Stem-and-Leaf Plot

Frequency Stem \& Leaf

1.00 Extremes $\quad(=<1.0)$

6.002 .000000

.002 .

14.003 .00000000000000

.003 .

$9.00 \quad 4.000000000$

Stem width: 1.00

Each leaf: 1 case(s) 


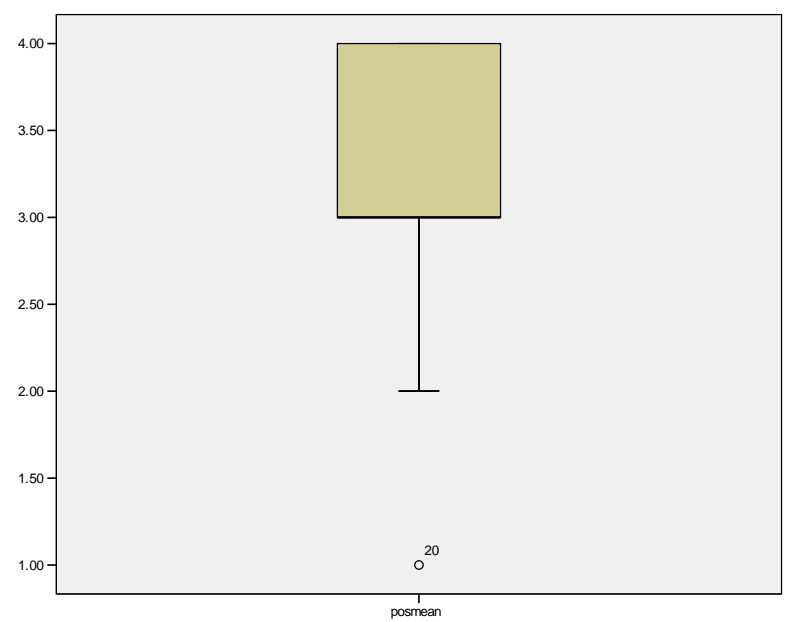

Statistics

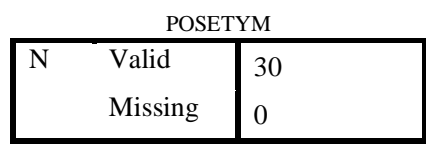

POSETYM

\begin{tabular}{|c|c|c|c|c|c|}
\hline & & Frequency & Percent & $\begin{array}{l}\text { Valid } \\
\text { Percent }\end{array}$ & $\begin{array}{l}\text { Cumulative } \\
\text { Percent }\end{array}$ \\
\hline \multirow[t]{6}{*}{ Valid } & .00 & 1 & 3.3 & 3.3 & 3.3 \\
\hline & 1.00 & 2 & 6.7 & 6.7 & 10.0 \\
\hline & 2.00 & 7 & 23.3 & 23.3 & 33.3 \\
\hline & 3.00 & 17 & 56.7 & 56.7 & 90.0 \\
\hline & 4.00 & 3 & 10.0 & 10.0 & 100.0 \\
\hline & Total & 30 & 100.0 & 100.0 & \\
\hline
\end{tabular}

DESCRIPTIVE STATISTICS

\begin{tabular}{|l|l|l|l|l|l|}
\hline & $\mathrm{N}$ & Minimum & Maximum & Mean & Std. Deviation \\
\hline posetym & 30 & .00 & 4.00 & 2.6333 & .88992 \\
Valid N (listwise) & 30 & & & & \\
\hline
\end{tabular}

CASE PROCESSING SUMMARY

\begin{tabular}{|c|c|c|c|c|c|c|}
\hline & \multicolumn{6}{|c|}{ Cases } \\
\hline & \multicolumn{2}{|c|}{ Valid } & \multicolumn{2}{|c|}{ Missing } & \multicolumn{2}{|c|}{ Total } \\
\hline & $\mathrm{N}$ & Percent & $\mathrm{N}$ & Percent & $\mathrm{N}$ & Percent \\
\hline posetym & 30 & $100.0 \%$ & 0 & $.0 \%$ & 30 & $100.0 \%$ \\
\hline
\end{tabular}

DESCRIPTIVES

\begin{tabular}{|lll|l|l|}
\hline & & Statistic & $\begin{array}{l}\text { Std. } \\
\text { Error }\end{array}$ \\
\hline posetym & Mean & & 2.6333 & .16248 \\
& 95\% Confidence & Lower & 2.3010 & \\
& Interval for Mean & Bound & & \\
& Upper & 2.9656 & \\
& Bound & & \\
5\% Trimmed Mean & & 2.6852 & \\
Median & & 3.0000 & \\
Variance & & .792 & \\
Std. Deviation & & .88992 & \\
Minimum & & .00 & \\
Maximum & & 4.00 & \\
Range & & 4.00 & \\
Interquartile Range & & 1.00 & \\
Skewness & -1.062 & .427 \\
Kurtosis & & 1.682 & .833 \\
\hline
\end{tabular}


posetym Stem-and-Leaf Plot

Frequency Stem \& Leaf

1.00 Extremes $\quad(=<.0)$

$2.00 \quad 1.00$

$.00 \quad 1$.

$7.00 \quad 2.0000000$

.002 .

$17.00 \quad 3.00000000000000000$

.003.

$3.00 \quad 4.000$

Stem width: 1.00

Each leaf: 1 case(s)

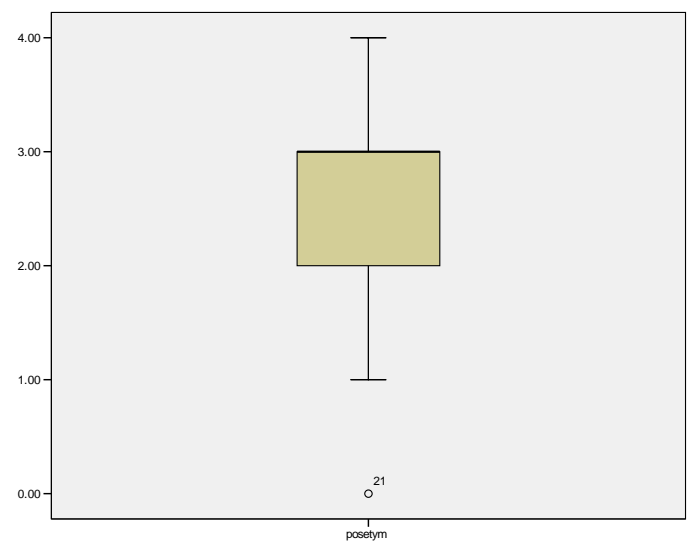

Statistics

POSINCID

\begin{tabular}{|ll|l|}
\hline $\mathrm{N}$ & Valid & 30 \\
& Missing & 0 \\
\hline
\end{tabular}

POSINCID

\begin{tabular}{|cl|l|l|l|l|}
\hline & & & & \\
& & Frequency & Percent & Valid Percent & Cumulative Percent \\
\hline Valid & 1.00 & 2 & 6.7 & 6.7 & 6.7 \\
& 2.00 & 9 & 30.0 & 30.0 & 36.7 \\
3.00 & 9 & 30.0 & 30.0 & 66.7 \\
4.00 & 10 & 33.3 & 33.3 & 100.0 \\
Total & 30 & 100.0 & 100.0 & \\
\hline
\end{tabular}

DESCRIPTIVE STATISTICS

\begin{tabular}{|l|l|l|l|l|l|}
\hline & $\mathrm{N}$ & Minimum & Maximum & Mean & Std. Deviation \\
\hline posincid & 30 & 1.00 & 4.00 & 2.9000 & .95953 \\
Valid N (listwise) & 30 & & & & \\
\hline
\end{tabular}

CASE PROCESSING SUMMARY

\begin{tabular}{|c|c|c|c|c|c|c|}
\hline & \multicolumn{6}{|c|}{ Cases } \\
\hline & \multicolumn{2}{|c|}{ Valid } & \multicolumn{2}{|c|}{ Missing } & \multicolumn{2}{|c|}{ Total } \\
\hline & $\mathrm{N}$ & Percent & $\mathrm{N}$ & Percent & $\mathrm{N}$ & Percent \\
\hline posincid & 30 & $100.0 \%$ & 0 & $.0 \%$ & 30 & $100.0 \%$ \\
\hline
\end{tabular}




\begin{tabular}{|lll|l|l|}
\hline \multicolumn{3}{|c|}{ DESCRIPTIVES } \\
\hline & & Statistic & $\begin{array}{l}\text { Std. } \\
\text { Error }\end{array}$ \\
\hline posincid & Mean & & 2.9000 & .17518 \\
& 95\% Confidence & Lower & 2.5417 & \\
& Interval for Mean & Bound & & \\
& & Upper & 3.2583 & \\
& Bound & & \\
5\% Trimmed Mean & & 2.9444 & \\
Median & & 3.0000 & \\
Variance & & .921 & \\
Std. Deviation & & .95953 & \\
Minimum & & 1.00 & \\
Maximum & & 4.00 & \\
Range & & 3.00 & \\
Interquartile Range & & 2.00 & \\
Skewness & & -.291 & .427 \\
Kurtosis & & -1.005 & .833 \\
\hline
\end{tabular}

posincid Stem-and-Leaf Plot

Frequency Stem \& Leaf

$2.00 \quad 1.00$

.001 .

$9.00 \quad 2.000000000$

.0022

$9.00 \quad 3.000000000$

.003 .

10.00 4. 0000000000

Stem width: 1.00

Each leaf: 1 case(s)

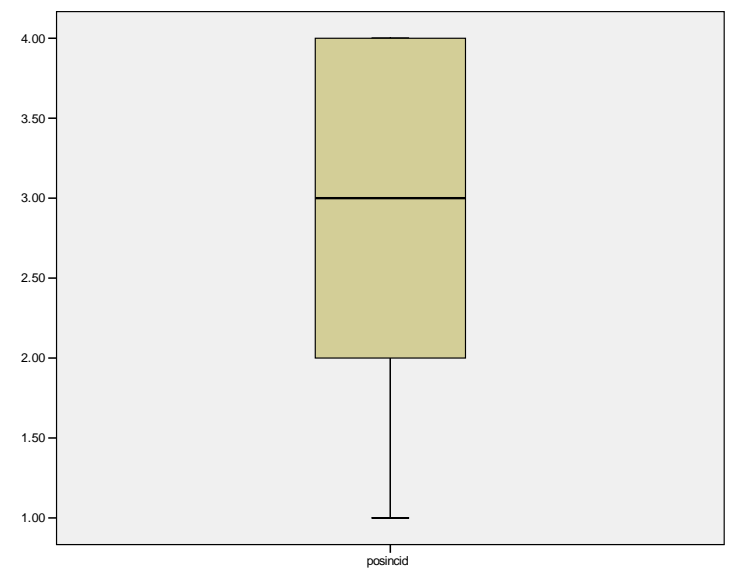

APPENDIX D. LINEAR REGRESSION

\begin{tabular}{|l|l|l|l|}
\hline \multicolumn{4}{|c|}{ DESCRIPTIVE STATISTICS } \\
\hline Mean & Std. Deviation & $\mathrm{N}$ \\
\hline posttest & 12.9000 & 2.70823 & 30 \\
posmean & 3.0333 & .80872 & 30 \\
posetym & 2.6333 & .88992 & 30 \\
posincid & 2.9000 & .95953 & 30 \\
\hline
\end{tabular}




\begin{tabular}{|c|c|c|c|c|c|}
\hline \multicolumn{6}{|c|}{ CORRELATIONS } \\
\hline & & posttest & posmean & posetym & posincid \\
\hline \multirow[t]{4}{*}{ Pearson Correlation } & posttest & 1.000 & 631 & .642 & .660 \\
\hline & posmean & .631 & 1.000 & .065 & 227 \\
\hline & posetym & .642 & .065 & 1.000 & .359 \\
\hline & posincid & .660 & .227 & .359 & 1.000 \\
\hline \multirow[t]{4}{*}{ Sig. (1-tailed) } & posttest & & .000 & .000 & .000 \\
\hline & posmean & .000 & . & .366 & .114 \\
\hline & posetym & .000 & .366 & . & .026 \\
\hline & posincid & .000 & .114 & .026 & . \\
\hline \multirow[t]{4}{*}{$N$} & posttest & 30 & 30 & 30 & 30 \\
\hline & posmean & 30 & 30 & 30 & 30 \\
\hline & posetym & 30 & 30 & 30 & 30 \\
\hline & posincid & 30 & 30 & 30 & 30 \\
\hline
\end{tabular}

\begin{tabular}{l} 
VARIABLES ENTERED/REMOVED(B) \\
\begin{tabular}{|l|l|l|l|}
\hline Model & Variables Entered & Variables Removed & Method \\
\hline 1 & posincid, posmean, posetym(a) & . & Enter \\
\hline
\end{tabular} \\
\hline \\
a All requested variables entered. \\
b Dependent Variable: posttest
\end{tabular}

\begin{tabular}{|l|l|l|l|l|}
\hline Model & $\mathrm{R}$ & R Square & Adjusted R Square & Std. Error of the Estimate \\
\hline 1 & $.936(\mathrm{a})$ & .876 & .862 & 1.00667 \\
\hline
\end{tabular}

\begin{tabular}{|ll|l|l|l|l|l|}
\hline \multicolumn{2}{|c|}{ ANOVA(B) } \\
Model & & Sum of Squares & df & Mean Square & F & Sig. \\
\hline 1 & Regression & 186.352 & 3 & 62.117 & 61.296 & $.000(\mathrm{a})$ \\
& Residual & 26.348 & 26 & 1.013 & & \\
& Total & 212.700 & 29 & & & \\
\hline
\end{tabular}

a Predictors: (Constant), posincid, posmean, posetym

b Dependent Variable: posttest

\begin{tabular}{|c|c|c|c|c|c|c|}
\hline \multirow[b]{2}{*}{ Model } & & \multicolumn{2}{|c|}{ Unstandardized Coefficients } & \multirow{2}{*}{$\begin{array}{l}\text { Standardized Coefficients } \\
\text { Beta }\end{array}$} & \multirow{2}{*}{$\mathrm{t}$} & \multirow{2}{*}{$\begin{array}{l}\text { Sig. } \\
\text { Std. Error }\end{array}$} \\
\hline & & $\mathrm{B}$ & Std. Error & & & \\
\hline \multirow[t]{4}{*}{1} & (Constant) & .809 & .921 & & .878 & .388 \\
\hline & posmean & 1.728 & .237 & .516 & 7.279 & .000 \\
\hline & posetym & 1.445 & .225 & .475 & 6.420 & .000 \\
\hline & posincid & 1.050 & .214 & .372 & 4.906 & .000 \\
\hline
\end{tabular}

a Dependent Variable: posttest

\section{REFERENCES}

[1] Alemi, M., Salehi, M., Khosravizadeh, P., Hatef, A. (2009). General English for science and engineering students. Tehran: Farhang Alem Publishing Co..

[2] Bot, K., and Paribakht, T, \& Wesche, M. (1997). Toward a lexical processing model for the study of second language vocabulary acquisition: Evidence from ESL reading. Sudies of Second Language Acquisition 19, 309-329.

[3] Cohen,C. \& Macaro, E. (2007). Language learner strategies. Oxford: Oxford University Press.

[4] Ehrman, M., Leaver, B., and Oxford, R. (2003). A brief overview of individual differences in second language learning. System 31, 313-330.

[5] Ellis, R,. \& he, X. (1999). The roles of modified input and output in the incidetal aqcuisition of word meanings. Studies of second Language Acquisition 21, 285-301.

[6] Ellis, R. (2008). The study of second language acquisition.( $2^{\text {nd }}$ ed). Oxford: Oxford University Press.

[7] Farhadi, H. (2006). Twenty-five years of living with applied linguistics: Collection of articles. Iran, Tehran. Rahnama press. 
[8] Gao, X. (2006). Understanding changes in Chinese students' uses of learning strategies in China and Britain: A socio-cultural re-interpretention. System 34, 55-67.

[9] Gass, S. (1999). Discussion: Incidental vocabulary learning. Sdudeis of Secon Language Acquisition 21, 319-333.

[10] Grainger, P. (2005). Second laguage learning strategies and Jepanese: Does orthography make a difference? System 33, 327339.

[11] Griffiths, C. (2003). Patterns of language learning strategy use. System 31, 367-383.

[12] Griffiths, C. (2006). Language learning strategies: Theory and research. Iran. ILI Language Teaching Journal 2, 1.

[13] Griffiths, C. (2008). Lessons from good language learners. Cambridge: Cambridge University Press.

[14] Hedge, T. (2000). Teaching and learning in language classrooms. Oxford: Oxford University Press.

[15] Hong-Nam, K. \& Leavell. A. (2006). Language learning strategy use of ESL students in an intensive English learning context. System 34, 399-415.

[16] Huckin, T \& Coady, J. (1999). Incidental vocabulary acquisition in a second language: A review. Studies of Second Language Acquisition 21, 181-193.

[17] Hulstijn, J. H., Boella, G., Damiano, R., Van der Torre, L. (2006). ACL semantics between social commitments and mental attitudes. Agent Communication II, International Workshops on Agent Communication. Selected and revised papers.

[18] Hulstijn, J. H. (2003). Insidental and intentional learning. In C. Doughty \& M. H. Long (eds). The handbook of second language acquisition (349-381). Oxford: Blackwell.

[19] Hunt, A., Beglar, D. (1998). Current research and practice in teaching vocabulary. The Language Teacher 22, (1).

[20] Hunt, A., \& Beglar. D. (2002). Current research and practice in teaching vocabulary. Methodology in language teaching: An anthology of current practice. Cambridege: Cambridge University Press.

[21] Jo Moir and Paul Nation. (2008). Vocabulary and good language learners. Lessons from good language learners. Cambridge: Cambridge University Press.

[22] Kasper, G., \& Schmith, R. (1996). Developmental issues in interlanguage pragmatics. Studies in Second Language Acquisition $18,149-169$.

[23] Khaldieh, S., A. (2000). Learning strategies and writing processes of proficient vs. less-proficient learners of Arabic. Foreign Language Annuals 33, (5), pp. 522-533.

[24] Krashen, S. (1989). Language acquisition and language education. Herts: England.

[25] Lawson, M. J., \& Hoghen D. (1996). The vocabulary-learning strategies of foreign-language students. Language Learning 46, (1): 101-135

[26] Magogwe, J. M. \& Oliver, R. (2007). Relationship between language self-efficacy beliefs, age, proficiency and language learning strategies, self-efficacy beliefs and age: An investigation. System Journal 35, (2007), pp. 353-367.

[27] Mondria, J, A., \& Wit-de Boer, M. (1991). The effects of contextual richness on the guessability and the retention of words in a foreign language. Applied Linguistics 12, 249-267.

[28] Nation, P. (1990). Teaching and learning vocabulary. New York: Newbury House.

[29] Nation, P. (2001). Learning vocabulary in another language. Cambridge: Cambridge University Press.

[30] Nation, P. (2002). Best practice in vocabulary teaching and learnning. Methodology in language teaching: An anthology of current practice. Cambridege: Cambridge University Press.

[31] Nyiazadeh, A. (2009). Input-outputEnhancement and Incidental Learning of Propositions. MA Thesis, Allameh-Tabatabayi University. Tehran, Iran

[32] Oxford, R. (2002). Language learning strategies in a nutshell: Update and ESL suggestions. Methodology in Language Teaching: An Anthology of Current Practice. Cambridege: Cambridge University Press.

[33] Oxford, R. (1990). Language learning strategies: What every teacher should know. Newbury House Publications.

[34] Oxford, R. L. \& Green, J. (1995). A closer look at learner strategies, L2 proficiency, and gender. TESOL Quarterly29, $261-297$.

[35] Paribakht, T. \& Wesche, M. (1997). Reading and incidental L2 vocabulay quisition: An introspective study of lexical inferencing. Studies of Second Language Aqcuisition 21, 195-224.

[36] Paribakht, T. \& Wesche, M. (1999). Incidential L2 vocabulary acquisition: Theory, current research and instructional implications. Thematic Issue: Studies in Second Language Acquisition 21, (2).

[37] Richards, J., \& Renandya, W. (2002). Methodology in language teaching: An anthology of current practice. Cambridege: Cambridge University Press.

[38] Rott, S. (1999). The effect of exposure frequency on intermediate language learner's incidental vocabulary acquisition and rtention through reading. Studies of Secon Language Aqcuisition 21, 589-619.

[39] Rubin, J. (1975). What the "good language learner" can teach us. TESOL Quarterly, 9, 41-51.

[40] Stern, H. H. (1975). What can we learn from the good language learner? Canadian Modern Language Review, 31 , $304-318$.

[41] Tajeddin, Z. (2006). Language learning strategies after 30 years of research. ILI Language teaching Journal 2, No 1.

[42] Wharton, G. (2000). Language learning strategy use of bilingual foreign language learners in Singapore. Language Learning 50, (2) (2000), pp. 203-243.

[43] Wode, H. (1999). Incidental vocabulary aqcuisition in the foreign language classroom. Sudies of Second Language Aqcuisition $21,243-258$. 


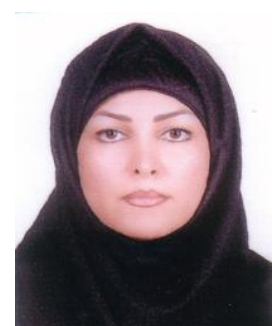

Minoo Alemi was born in Iran. She has been a Ph.D. candidate of TEFL (Teaching English as a Foreign Language) at Allameh Tabataba'i University in Tehran, Iran since September 2009. She graduated B.A. in English literature and M.A. in TEFL at Allameh University and Khatam University in Tehran.

As for her professional background, she has taught English over a decade at different universities in Iran. Moreover, she has been faculty member and vice-Dean of Education at Languages and Linguistics Department at Sharif University of Technology since 2008. Her main areas of interest are (1) second language acquisition, (2) ESP, (3) vocabulary, and (4) syllabus design. Alemi has published about ten textbooks in General English and ESP, a large number of papers in different areas in international journals, and given presentations on TEFL at many international conferences.

Ms. Alemi is a member of scientific board of LiBRI, Linguistic and Literary Broad Research and Innovation journal and JLTR, Journal of Language Teaching and Research.

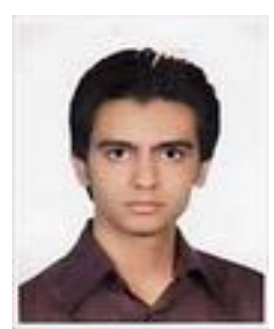

Alireza Tayebi was born in Tehran, Iran on Feb. seventh, 1986. He got his B.A in English literature from Sheikh Bahayee University (SHBU) in Isfahan, Iran, in 2009. Now he is an M.A student of Applied linguistics and working as Teacher Assistant at Sharif University of technology, Tehran, Iran. 